\title{
CHALLENGING STEREOTYPES WITH MEDIA AND INFORMATION LITERACY IN MEXICO
}

Julieta Flores Michel :: Margarita Emilia González Treviño :: Alma Elena Gutiérrez Leyton

ORIGINAL SCIENTIFIC PAPER / DOI: 10.20901/ms.10.19.4 / SUBMITTED: 07.05.2019.

\begin{abstract}
Information overload that affects digital natives and other generations in the 21st century makes it difficult for recipients to analyze the information's truthfulness and quality. In this context, items of fake news pass as facts that could be interpreted as true, which may result in serious issues for the social fabric, especially if immersed in unstable or troublesome political and economic contexts. Still, the problem with disinformation is not limited to fake news because, even when content comes from trustworthy sources and verifiable facts, there are filters that present a subjective, biased and deformed reality. Within this context, we are submitting an example of a positive practice in media literacy targeting Research Methodology students at the Faculty of Communication. During this project, students analyzed the way women and men are shown on the cover of a local printed newspaper El Porvenir in the city of Monterrey, Mexico. In broad strokes, the results found a preference for stories showcasing men and stereotypes that place men in the public sphere and women in a private domain.
\end{abstract}

\section{KEYWORDS}

MIL, FAKE NEWS, TRUSTWORTHY SOURCE, NEWS ARTICLES, GENDER STEREOTYPES, BIASED INFORMATION

Authors note

Julieta Flores Michel :: Autonomous University of Nuevo Leon,

Faculty of Communication Sciences, Monterrey, Mexico :: julietaflores@hotmail.com

Margarita Emilia González Treviño :: Autonomous University of Nuevo Leon,

Faculty of Communication Sciences, Monterrey, Mexico :: maguiegzzt@gmail.com

Alma Elena Gutiérrez Leyton :: Autonomous University of Nuevo Leon, F

aculty of Communication Sciences, Monterrey, Mexico :: agutierrezleyton@gmail.com 


\section{INTRODUCTION}

The premise that says "more information does not mean better information" is no longer up for discussion - instead, it suggests the paradox of disinformation. The risks of a misinformed society are serious and do not come solely from fake news published by dubious sources. The sources we consider trustworthy, those which provide "real" news, can give us a biased or partial view of reality in both traditional and digital media by showing half-truths and presenting an incomplete, and even biased, reality.

From the perspective of journalism, the expression 'fake news' cannot be translated literally. In effect, if news is false, it is not news, because in journalism, in principle, there is no false news, so much so that one of the rules is - verification of the facts before publication. However, the expression covers several categories - fraudulent or fragile news; false information (generally with forged sources), manipulated, adulterated or manufactured or 'planted' (with the intention of deceiving) (...) old news; sensationalism (typical of tabloids) lies, makeup, rumors, alternative events etc. - all of which threaten the quality of journalism (Parreira, 2019: 92).

In case of social networks, this verification is not a condition due to the fact that a person who produces some content is not necessarily a professional journalist and can be any citizen with access to technology that has an account on social networks and desires to communicate his or her thoughts. This freedom of production and dissemination of content allows social networks to disseminate all types of content that can be false, manipulated, adulterated or planted (based on the above definitions).

Fake news is not a new phenomenon, unlike the extent to which it can be reproduced on social networks. "The fact that the concept of 'fake news' has been adopted in a number of languages indicates the importance of this phenomenon. The loss of centrality of the source, 'viralization', etc. - often diminish interest in the veracity of the news and the critical reading abilities to identify the false. Due to the fact that large proportions of population are registered on social networks, these issues have very direct political consequences, as it was seen in several recent events (Fernández-García, 2017: 66). Recently, it has been called 'post-truth', a concept that was selected by the Oxford Dictionary as 'the international word of the year 2016'. The same dictionary defined it as "the circumstances in which the objective facts influence less in the formation of public opinion those that refer to emotions and personal beliefs" (ibid.: 67). "It is a falsehood that continues to be accepted even knowing that it is a false, which does not prevent decisions based on it" (ibid.: 67).

In this sense, citizens with media education must have, develop and use competencies to differentiate false from truthful information; detect biases; analyze the context in which the message is being transmitted; classify the source; check and compare the information against other trustworthy sources; and, if needed, spread only the information they have analyzed with these competencies, always keeping in mind the importance of showing respect to all the parties involved in this complicated communication process. 
ORIGINAL SCIENTIFIC PAPER / DOI: 10.20901/ms.10.19.4 / SUBMITTED: 07.05.2019.

Today, developing these competencies has become essential because, since the printing press first appeared, we have never had so much information available and so much technology to access it easily. Having a mobile device connected to the Internet is more than enough for a user to, literally, access all the information in the world. Even though the problem for Media Education does not circumscribe to digitally-broadcast content, it is important to stress that information overload is indeed caused by the technological advances in digital communication and the Internet, which, in the late 2010s, is represented by a boom of smartphone technologies.

Cheaper and more accessible than a couple of decades ago, smartphones have revolutionized the process of human communication. These devices have combined communication models that needed unique and different processes and channels, such as: interpersonal, group, public and mass communication (Cantú et al., 2009). With these four communication processes now integrated in one communication channel, the economically active population of the $21^{\text {st }}$ century has a more immediate access to even more, and frequently free, information.

For example, in $2016,64.9 \%$ of Mexico's population had Internet access, which equaled 71.3 million users. By 2017, 72.2\% of the population aged 6 and older used a cell phone, and $80 \%$ of this population used a smartphone, which was also the most frequently mentioned device for connecting to the Internet, showing a preference of $89.7 \%$. These same Internet users chose, with a lower percentage of preference, other devices to connect to the Web, such as PCs, smart TVs, Video Game Consoles, and Tablets (INEGI, SCT and IFT, 2018).

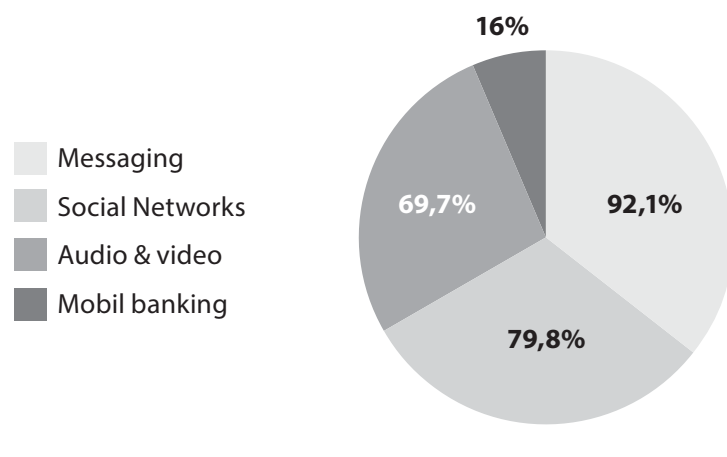

A Figure 1.

Apps installed by smartphone users in Mexico (2017).

Source: INEGI SCT, and IFT, $2018^{1}$

With these numbers, as shown in Figure 1., we can easily see, as mentioned earlier, how cellular devices merge interpersonal communication (one-on-one using direct voice

\footnotetext{
${ }^{1}$ Information based on 36.4 million people according to INEGI's nationwide survey in 49 Mexican cities in rural and urban regions (INEGI, SCT, and IFT, 2018).
} 
calls or personal messages), small-groups communication (a limited number of people in a group getting in touch simultaneously and with certain order), public communication (forums, blogs) and even mass communication (news and advertisement from diverse sources), as well as many other activities added every day to these devices.

This is how the massification of Internet use brought about an overload in information sent and received by users and how it also changed the roles of issuers and recipients, who in turn have become spreaders of information not created by them.

In a context of public communication instead of personal, and according to their origin, we identified in this analysis two types of messages in information overload:

a. Formal Messages that transmit information created by traditional communication media such as press, radio and television and based on a source acknowledged as official or authoritative.

b. Informal Messages that transmit entertainment, social commentary, derisive or thought-provoking content based on images, videos, and short messages without an identifiable source

Both types of messages are, or could be, the spark that sets the decision-making process of the average citizen in motion. These types of messages may influence decisions such as:

$>$ who to vote for in the next election?

$>$ how to invest for retirement?

$>$ where to live?

$>$ who to trust?

>what position to have regarding immigrants, senior citizens, non-cisgender people, poor and rich people, women, or children?

$>$ whether to accept the anonymous challenges in social media?

$>$ whether to share the information received over social media from contacts or groups?

Even when these situations represent a small sample, they affect society's sustainable development. Is getting a lot of positive or negative information regarding a politician sufficient to define a person's position and a person's vote? How many people really think that more information means greater knowledge?

In order to have a diagnostic view of the stance of social media users on information they receive, we applied a 24-item questionnaire on a sample of 40 people. Participants were $66.6 \%$ female and $33.3 \%$ male; $75 \%$ had a bachelor's degree and $16.6 \%$ had a master's degree. Therefore, we assume it is a population with greater MIL competencies. In this sample, $73.9 \%$ said that memes should be 'funny' to merit sharing while options like 'human value' and 'general interest' scored $13 \%$ each.

It is not a statistically representative sample, but the instrument's pilot exercise, which will be applied massively in the second phase. 
Regarding the question "Do you think the news you get on events and facts are true?" there was a balance in contradictory positions since $41.6 \%$ answered "almost always real" and $45 \%$ answered "seldomly real". In other words, a significant percentage of people, notwithstanding the fact that they have obtained academic degrees, do not question the source and credibility of the information they get. In this sample, only $39.1 \%$ said they "seldomly" checked the information they got, $34.7 \%$ said they "always" did, while $26 \%$ said "almost always".

The paradox of disinformation, as seen in this small sample, transcends gender and academic degree. Therefore, it is important for the governments of different countries to work on Public Policies for Media Literacy. However, this effort is not easy. The first problem we see is the definition of the concept, which can be: Media Education (ME), Media and Information Literacy (MIL), Computer Literacy and Digital Literacy (Frau-Meigs et al., 2017), among others. Even when all these concepts have their own goals and characteristics, we need to integrate and direct the competencies deriving from each of them, as directed by the European Union in 2007, into a Media Literacy that gives people: "the ability to access, understand, and critically assess different aspects of their contents, as well as to establish ways to communicate in diverse contexts" (Frau-Meigs et al., 2017).

To promote the development of media literacy competencies, countries have different players, as pointed out by Divina Frau-Meigs et al. (2017) in the book Public Policies in Media and Information Literacy in Europe, cross-country Comparisons which included the analysis of 28 countries in the European Union. These players were identified as: partnerships outside, regulation media authorities, private sector, civil society organization, youth participation, professional organization of specific events and overlapping structures.

Meanwhile, the strategies to develop media literacy competencies range from including them via formal education at basic and upper education institutions, to nonformal education through government campaigns and other actions carried out by the above-mentioned players. In Mexico, there is content supporting MIL at every level in the education sector. We can find, for example, computer courses developing technical competencies on how to use a PC and different software; there are also comprehensive training courses that, without having been specifically created for media literacy, strengthen the competencies needed for MIL.

In this context, Mexico's current Secretary of Education, Esteban Garza Moctezuma, said that Civics and Humanism are essential courses for preserving a healthy social fabric:

In this new stage in the country's public education, Civics and Humanism are two of the courses in the New Mexican School's curriculum that aim to prepare citizens for life through comprehensive development, helping them be ready for coexisting and not just ready for work (Ministry of Public Education, 2019).

Regarding non-formal education, Mexico's Government also carries out other actions to promote Public Policies that support the rights of audiences. This is the case of the Federal Telecommunications Institute $\left(\mathrm{IFT}^{2}\right)$, which was created in 2013 to make sure

\footnotetext{
${ }^{2}$ The Federal Telecommunications Institute's acronym in Spanish
} 
the concessionaries of the country's media respect the following guidelines: (Federal Telecommunications Institute, n.d., section II of The Rights of Audiences in its Article 5, pages 7 to 9):

I. Human rights, the greater need of children, and gender equality

II. Content free of discrimination

V. Broadcast shows promoting family integration, sustainable development, the spread of technical and scientific knowledge, and the accurate use of language.

XI. Truthful and timely information.

XXIV. Set mechanisms and programs to promote and contribute to media literacy.

Article 5 also highlights how important it is for audiences to receive content where they can clearly tell what is news and what are the host's opinions; as well as differentiate advertisement from content and, as the document states, avoid broadcasting "advertising or propaganda passing as news or reporters' work" (IFT, n.d., Article 5/XVI, page 9).

By creating the IFT, Mexico has taken a major step towards creating new public policies focusing on the promotion of diverse laws and regulations, such as policies supporting and defending audiences, but the challenge remains to understand how citizens can really exert this right.

Aware that education is the best way to achieve media literacy, this paper analyzes an example of positive MIL practices in the framework of formal education at a bachelor's degree level. We specifically show the strategy used for students of the Universidad Autónoma de Nuevo León's Faculty of Communication Sciences to develop competencies to become an active audience. This experience is part of the Research Methodology for Communication Sciences course, where we transversally teach the scientific method and the Lines of Knowledge Generation as set by the professor in charge of the course, which in our case are MIL and Gender Studies Lines.

The problem presented to the students was based on Article 5, paragraph I from the document called General Guidelines for the Rights of Audiences (IFT, n.d.), which includes gender equality. The specific problem was to analyze the roles males and females play in the cover of a local paper in the city of Monterrey, Mexico, based on gender stereotypes.

To carry out this analysis, undergraduate students supported their research on Communication Sciences theories and on documents covering the State of the Domestic and International Arts. Once the theoretical framework was set, students worked with the assigned methodology and then presented their results and conclusions based on the established hypotheses and assumptions as well as on the research questions. In this sense and this order, this paper honors the information covered by the students under the guidance of this paper's authors, as a positive MIL practice experience. 
ORIGINAL SCIENTIFIC PAPER / DOI: 10.20901/ms.10.19.4 / SUBMITTED: 07.05.2019.

\section{PROBLEM STATEMENT}

In society, and through the years, women have always been placed in an inferior position to men and, consequently, they have been victims of labor inequality, lack of job opportunities, and even physical abuse. The progress of science and technology fosters new knowledge. It would seem obvious that equality in the rights of women and men should move forward shoulder to shoulder to favor a fair balance, but we do not see this happening at the same rate as technological and scientific growth. Mass media, in their traditional and digital formats, are involved in the promotion of this imbalance, this lack of equality in the rights and obligations of women and men; sometimes by manipulating the information they publish, sometimes by projecting gender stereotypes on actors of their content, strongly tipping the scales towards women for the worse.

The reality of the world received by audiences is one chosen by the editors and CEOs of the media. They are the ones choosing which items of news are more relevant, the tone in which they are presented (satirically, ironically, supporting or undermining the event they cover), which actors are more relevant between women and men, and how these actors are shown in the news.

The research's general and specific questions arose from this position.

General Question:

> How are men and women showcased on the cover of a free, printed newspaper in Monterrey, Mexico?

Specific Questions:

$>$ What is the ratio of news showcasing men and women on the cover of a local free, printed newspaper in Monterrey, Mexico?

$>$ What is the space in square inches occupied by images of men and women on the cover stories of this newspaper?

$>$ Which stereotypes are present for men and women on the cover stories of this newspaper?

The following are the hypotheses and assumptions for this research:

$>$ Men are shown in a better light and with higher reputation while women are shown in inferior roles and, sometimes, they are absent.

$>$ The number of items of news showcasing men as the main subject is greater than those showcasing women.

$>$ The space of text in square inches showcasing men is greater than the space showcasing women on the cover stories of the newspaper.

$>$ News includes content with gender stereotypes.

$>$ Gender stereotypes in the news show gender inequality. 


\section{RESEARCH PROBLEM'S CONCEPTUAL FRAMEWORK}

This research is based on Gender and Communication theories, as shown below.

\section{Gender Theories}

The gender theory arose as a counterpart to the biological theory; it deals with a social construct that we can modify so that women and men can coexist while remaining different and of equal value. Marta Lamas (1999), a Mexican feminist, defines the gender concept as: "the set of ideas, representation, practices, and social prescriptions developed by culture from the anatomical difference of sexes, to symbolize and build socially what is proper of men (the masculine) and what is proper of women (the feminine)," (Lamas, 1999: 84).

In this sense, masculine and feminine traits are not inherent to the reproductive organs, but they are to the social construct deriving from the social imaginary of those organs. Thus, the concept of gender asserts that the characteristics allocated to sex come from the cultural context and not from nature. We are saying then that we decide what these characteristics should be based on our perception of what each society and culture think men and women should be. Therefore, these characteristics may change from one culture to another. The characteristics of what men and women are, and should be, thus become stereotypes.

From the perspective of social psychology, as stated by Pascaline Gaborit (2009), a stereotype has a neutral meaning because it allows for an internal restructuring of the world where "the stereotype is the action through which a person is associated to a particular category," (Brawn, R. 1995, as cited in Gaborit 2009). Yet, when we speak about gender stereotypes, the word stereotype loses its neutrality and becomes a scarlet letter where women are branded with the most negative and less favorable of the categories defining human beings.In this sense, when a stereotype is the way we rationalize the extreme beliefs associated to the behavior or characteristics of certain persons or groups (Allport, G.W. 1954, as cited in Gaborit 2009), it becomes a social imaginary that leads to gender discrimination in a relationship of power where women are submissive or dominated and men are dominant physically, financially, socially and in all spheres of power such as politics, sports or religion.

To analyze the study case proposed in this paper, it is important for us to define the concept of sexism; according to Morgade (2001, page 11, as cited by Araya, 2005): "It is a form of discrimination because, just as other forms of discrimination, it is a practice that tends to pigeonhole people in imposed parameters". These parameters affect both men and women, but tend to favor men, placing women in inferiority, as mentioned before.

Within this context, the idea of gender is built upon social perceptions. And these perceptions, as culturally stereotyped by mass media, generate behaviors. 
ORIGINAL SCIENTIFIC PAPER / DOI: 10.20901/ms.10.19.4 / SUBMITTED: 07.05.2019.

\section{Communication Theories}

The goal of knowledge is truth, and we expect formal mass media such as press, radio, television - at least in their informative function - to deliver that truth to audiences who, in turn, cast their vote of confidence and credibility to the opinion leaders in different news spaces. Working with the assumption that media does not show the truth, students supported the research problem on the 'gatekeeper theory', which had in Kurt Lewin one of its most important supporters in the 1970s (Lozano, 2007). This theory follows a positivist empirical vision and an analysis of how newspapers editors "chose certain news and dismissed others," (Lozano, 2007: 34); which supports the fact that audiences, or readers, get only partial information on reality.

A weakness of this theory is the fact that it minimizes the information selection process to simple personal or arbitrary decisions of editors. Thus, other and more complex studies were developed, such as The Sociology of the Production of Messages. This research trend from the mid-1970s - with representatives such as Shoemaker and Reese (1991), Mauro Wolf (1987), Jesús María Aguirre (1992), and Michael Shudson (1997) - included the analysis of more complex variables such as factors organizations cannot control: media policies, the financial and ideological systems of the context, and others; and internal factors e.g. the communicators' personal attitudes and values (Lozano, 2007).

The research exercise carried out by students of the Faculty of Communication did not contemplate analyzing the causes or effect of the selection of the information published by the newspaper because the goal was for students to observe whether this selection had an effect on the roles of men and women on the newspaper's cover page. Next, we will describe the methodology we used to carry out this project.

\section{METHODOLOGY FRAMEWORK}

The research problem came from three specific goals, the first two focused on observing and measuring quantitively the spaces on the newspaper's cover showcasing men and women and the third goal aimed to analyze abstract qualities, as shown in Figure 2. Therefore, we worked with a mixed method that allowed researchers to have a "crossing of approaches" (Lincoln and Gubba, 2000 as cited in Hernández et al., 2006), thus providing a holistic view for the issue.

In the mixed method, the qualitative vision gives the issue a better understanding, complexity and depth, while the quantitative vision strengthens the analysis of the frequency, amplitude, and magnitude (Creswell, 2005, as cited by Hernández et al., 2006). The integrating strategy we used corresponds to the supplementary mixed method, also called 'parallel design method', because it was deemed as the best fitting to the problem and the most appropriate rationally (Creswell, 2005, as cited by Hernández et al., 2006). This parallel design let us contrast the qualitative and the quantitative results, combining the advantages of both processes. 


\section{Quantitative objectives}

$>$ Identity the ratio of news showcasing men and women on the cover of a local, free printed newspaper in Monterrey, Mexico >Learn how much space in square inches is devoted to images of men and women on the cover stories of the newspaper

\section{Qualitative objectives}

$>$ Identity the gender stereotypes for men and women present on the cover notes of this newspaper

\section{Quantitative variables}

$>$ Number of notes on the cover $>$ Number of $\mathrm{cm} 2$ of notes

$>$ Amount of $\mathrm{cm} 2$ in images

\section{Qualitative variables}

$>$ Male gender stereotypes

$>$ Female gender stereotypes

A Figure 2 .

Justification of the Mixed Method.

We used the content analysis technique and observation grids for both quantitative and qualitative data. We chose a freely distributed local newspaper El Porvenir in Monterrey, Mexico. The sample consisted of the cover pages of the newspaper during the period of one month (March to April 2015), which resulted in the analysis of twelve cover pages. We chose a printed newspaper over a digital one for this exercise because the format made it easier for students to perform a quantitative analysis of the data.

\section{CONTENT ANALYSIS RESULTS}

The first research question was: "What is the ratio of news showcasing men and women on the cover of a local, free newspaper El Porvenir in Monterrey, Mexico?

Systematically, the newspaper we examined had four stories on the cover. Therefore, we analyzed 48 stories. As it can be seen in Figure 3, a significant space was dedicated to men.

Men

Women

Mixed notes

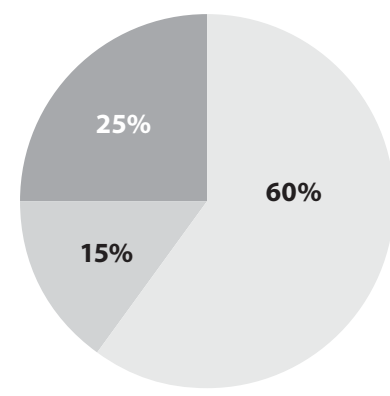

A Figure 3.

Ratio of news showcasing men and women in a local printed newspaper in Monterrey, Mexico. 
This first result shows an enormous advantage for men: they were showcased as the main subject in 29 cover stories out of 48 in the month's total. Meanwhile, only seven of them showcased women as the main subject in the same period.

The second resesearch question was: "What is the space in square inches for images of men and women on the newspaper's cover stories?"

The results showed that from a total of 316.51 square inches of images analyzed on the newspaper's cover, 272.65 square inches showed men, while women were present in just 43.86 square inches. This clearly shows a tremendous inequality in terms of the size of images devoted to the two sexes.

Table 1.Presence of men and women in the images on the cover page of a local, printed newspaper in Monterrey, Mexico

\begin{tabular}{lll}
\hline Men & Women & Total \\
\hline 272.65 sq. in. & 43.86 sq. in. & 316.51 sq.in. \\
$86.14 \%$ & $13.85 \%$ & $99.99 \%$ \\
\hline
\end{tabular}

The qualitative question was: "Which stereotypes of men and women are shown in the cover stories of a local, printed newspaper in Monterrey, Mexico?"

It was established that in the twelve issues collected during the month-long observation, and according to the definition and stereotypes set in the theoretical framework, the following labels were used for stereotypes applicable to men: authoritarian, argumentative, decisive, satisfied, possessive. For women, students identified fewer labels: submissive, vulnerable, and protective. The categories that constitute stereotypes emerged as a result of the qualitative analysis of the pages in an exercise in 'grounded theory' (Lincoln and Gubba, 2000, as cited in Hernandez et al., 2006).

For stereotypes applicable to men, students identified connotations that presuppose a domination of the public sphere by males, as seen in Figure 4.

In their own words, students who carried out this investigation asserted:

The number of stereotypes we found for women were nominal and, unfortunately, none of them depicted women in a different light; all the stereotypes used for women imply they are still seen as weaker in comparison to men. From seven cover stories in a month, four depict women as submissive, one as vulnerable, and two as protective.

As shown in Figure 5., we concluded that these stereotypes placed women definitively in the private sphere. 


\section{Authoritative \\ Decisive \\ Argumentative \\ Direct \\ Satisfied \\ Possesive}

Submissive

Vulnerable

Protective

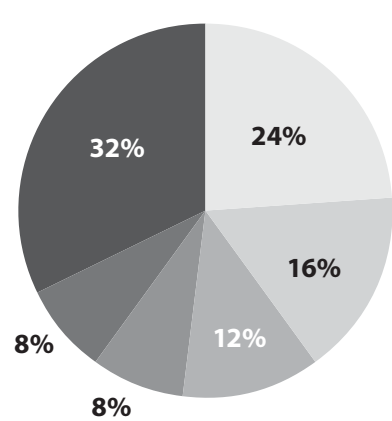

$\Delta$ Figure 4.

Stereotypes applicable to men in the cover stories of a local, printed newspaper in Monterrey, Mexico.

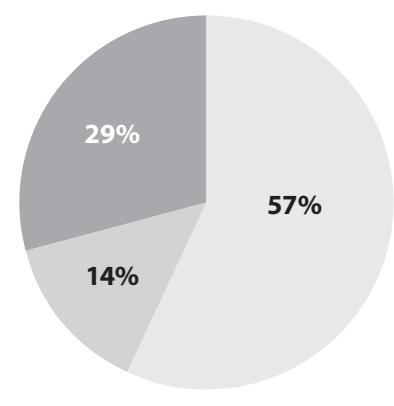

$\Delta$ Figure 5 . Stereotypes applicable to women found in the cover stories of a local, printed newspaper in Monterrey, Mexico.

\section{FINAL RECOMMENDATIONS AND DELIBERATIONS}

Media literacy education is a joint responsibility of the governments, families, societies, educational institutions, and other organizations. As seen from the viewpoint of formal education, both managers and teachers should implement specific actions that foster the development of MIL competencies in the curricula of the different educational plans, and at every educational level. Although it is important to have learning units that specifically address media literacy, teachers have the responsibility to permeate this topic transversally to every course, linking the development of these competencies to the work we do with our students in and outside our classrooms. Likewise, teachers who also carry out research work should guide the application of the scientific method on issues concerning our own areas of knowledge and following a MIL context. 
ORIGINAL SCIENTIFIC PAPER / DOI: 10.20901/ms.10.19.4 / SUBMITTED: 07.05.2019.

Digital natives cannot conceive a world without the information they get from the Internet on diverse devices and over different platforms. Therefore, it is essential for them to have the ability to discern truthful from false information; but they also, as we saw in the exercise we presented, need to tell apart and give a meaning to the filters over which that information is transmitted. It was very satisfying for the authors to read the students' comments:

We realize the theory we chose supports our goal and the research question (Kurt Lewin's Gatekeeper Theory, 1947), which states that mass media exert great influence over the public by choosing which stories are newsworthy and how much space and relevance they get. These lines are enough to make clear the newspaper we analyzed is more interested in presenting news that showcase men instead of women.

We concluded that the stereotypes applicable to men and women, as shown on the cover of the newspaper we studied, represent a broader form of inequality for women and that these stories foster more interest for the growth of men than for the growth of women; therefore, we accept our hypothesis.

The participation of women compared to that of men on the cover stories of the newspaper is negligible, it does not promote equality, and continue to depict the stereotypes that have applied for men and women for centuries; therefore, there is not any sort of equality among the sexes on the cover of the printed newspaper we studied for a month and, thus, the expected trend is for the newspaper to carry on depicting the same form of inequality in each of its issues.

Students also included important elements of media literacy in the recommendations they made for this project. The following is a selection:

Regarding theory and practice.

$>$ Monitor the proposed problem.

> Foster equality in all the media, especially among those who write for printed newspapers.

$>$ Provide writers with basic training to help foster a healthy coexistence and gender equality at work and in their writings.

$>$ Carry out annual research on the matter and check the progress made on equality.

Regarding methodology.

$>$ We recommend improving this research problem in the future by creating experimental quantitative studies.

Lastly, the authors suggest students introduce these types of academic activities that link different areas of knowledge with MIL in extra-curricular contexts such as forums and conferences within and outside academia as well as in informal contexts, such as neighborhood meetings, conferences for vulnerable groups, and, of course, among their relatives and friends.

Knowledge does not wear out and it enriches the lives of those who give it and those who receive it. Knowledge is a resource that supports the sustainable development of our planet. Let us keep promoting generations of students and their use of knowledge. 
ORIGINAL SCIENTIFIC PAPER / DOI: 10.20901/ms.10.19.4 / SUBMITTED: 07.05.2019.

\section{References}

>Araya Umaña, Sandra (2005) Relaciones sexistas en la educación [essay prepared for the "Education and gender" course of the Latin American Doctorate of Education of the State University, Costa Rica], Costa Rica: UNED.

$>$ Cantú Ortiz, Ludivina; Flores Michel, Julieta and Roque Segovia, Carmen (2009) Competencia comunicativa. México: Patria.

>Fernández-García, Nuria (2017) "Fake news": una oportunidad para la alfabetización mediática. Revista Nueva Sociedad 269: May - June 2017.

>Frau-Meigs, Divina; Velez, Irma and Flores Michel, Julieta (2017) Public Policies in Media and Information Literacy in Europe: Cross-Country Comparisons. London: Routledge. DOI: $10.4324 / 9781315628851$.

$>$ Gaborit, Pascaline (2009) Les stéréotypes de genre: Identités, rôles sociaux et politiques publiques. Paris: L'Harmattan.

> Hernández Sampieri, Roberto; Fernández Collado, Carlos and del Pilar Baptista Lucio, Maria (2006) Metodología de la investigación. México: McGraw Hill.

$>$ INEGI, SCT and IFT (2018) Comunicado de prensa núm. 105/18. http://www.beta.inegi.org.mx/ contenidos/saladeprensa/boletines/2018/otrtemecon/endutih2018_02.pdf (10/04/2019).

$>$ Instituto Federal de Telecomunicaciones, (n.d.) Lineamientos Generales sobre los derechos de la Audiencias. http://www.ift.org.mx/sites/default/files/industria/temasrelevantes/4746/documentos/ lineamientosdchosaudienciasaccesible.pdf (10/04/2019).

>Lamas, Marta (1999) Género, diferencias de sexo y diferencia sexual. Debate Feminista 20 (10): 84-106.

>Lozano Rendón, José Carlos (2007) Teoría e investigación de la comunicación de masas.

México: Pearson.

>Parreira do Prado, Magaly (2019) La proliferación de las "fake news" y sus algoritmos daña la cultura democrática. Ámbitos. Revista Internacional de Comunicación (45): 89-106.

>Ramírez Prado, Fidel and Rama, Claudio (eds), (2014) Los recursos de aprendizaje en la educación a distancia: Nuevos escenarios, experiencias y tendencias. Perú: Universidad Alas Peruanas and Virtual Educa.

$>$ Real Academia Española (2017) Sex concept. http://www.rae.es/ (10/04/2019).

$>$ Ministry of Public Education (2019) Boletín No. 57 Civismo y Humanismo, materias que regirán la matrícula de la Nueva Escuela Mexicana: EMB. https://www.gob.mx/sep/articulos/boletin-no57-civismo-y-humanismo-materias-que-regiran-la-matricula-de-la-nueva-escuela-mexicanaemb?idiom=es (25/04/2019). 


\section{MEDIJSKA I INFORMACIJSKA PISMENOST U SLUŽBI PROPITIVANJA STEREOTIPA U MEKSIČKIM DNEVNIM NOVINAMA}

\section{Julieta Flores Michel :: Margarita Emilia González Treviño :: Alma Elena Gutiérrez Leyton}

SAŽETAK Pretrpanost informacijama, koja pogađa ne samo digitalne urođenike nego i digitalne pridošlice, čini proces provjere istinitosti i kvalitete informacija sve složenijim. Zbog toga se često događa da lažne vijesti prolaze kao činjenice koje se interpretiraju kao istina. To može rezultirati ozbiljnim problemima za društveno tkivo, osobito ako se društva nalaze u nestabilnim političkim i gospodarskim kontekstima. Ipak, problemi s dezinformacijama nisu ograničeni samo na lažne vijesti jer, čak i kada sadržaj dolazi iz vjerodostojnih izvora i provjerljivih činjenica, postoje filtri koji predstavljaju subjektivnu, pristranu i deformiranu stvarnost. U ovom radu predstavljamo primjer pozitivne prakse s područja medijske pismenosti usmjeren na studente koji pohađaju kolegij Metodologija istraživanja na Fakultetu komunikacijskih znanosti u Monterreyu, u Meksiku. Studenti su analizirali kako se žene i muškarce prikazuje na naslovnicama jednih lokalnih tiskanih dnevnih novina u Monterreyu. Rezultati istraživanja pokazuju usmjerenost prema pričama koje u prvi plan stavljaju muškarce te ih stereotipno prikazuju u javnoj sferi, a žene u privatnoj.

\section{KLJUČNE RIJEČI}

MIP, LAŽNE VIJESTI, VJERODOSTOJNI IZVORI, NOVINSKI PRILOZI, RODNI STEREOTIPI, PRISTRANE INFORMACIJE

Bilješka o autoricama

Julieta Flores Michel :: Autonomno sveučilište Nuevo Leon,

Fakultet komunikacijskih znanosti, Monterrey, Meksiko :: julietaflores@hotmail.com

Margarita Emilia González Treviño :: Autonomno sveučilište Nuevo Leon,

Fakultet komunikacijskih znanosti, Monterrey, Meksiko :: maguiegzzt@gmail.com

Alma Elena Gutiérrez Leyton :: Autonomno sveučilište Nuevo Leon,

Fakultet komunikacijskih znanosti, Monterrey, Meksiko :: agutierrezleyton@gmail.com 